\title{
Mari Language
}

National Cancer Institute

\section{Source}

National Cancer Institute. Mari Language. NCI Thesaurus. Code C153879.

A language in the Uralic language family spoken primarily in the Mari Republic of the Russian Federation. 